\title{
Linear lichen planus in children - Case report
}

\author{
Líquen plano linear na infância - Relato de caso
}

Marcia Raquel Horowitz ${ }^{1}$

Manuela Oliveira Resende

Silvana Maria de Morais Cavalcanti²

\author{
Marcela de Lima Vidal ${ }^{1}$ \\ Márcia Almeida Galvão Teixeira² \\ Eliane Ruth Barbosa de Alencar ${ }^{3}$
}

DOI: $h$ ttp://dx.doi.org/10.1590/abd1806-4841.20131971

\begin{abstract}
Lichen planus is an uncommon disease in children, and only 2 to $3 \%$ of affected patients are under twenty years of age. This dermatosis may appear in several clinical forms, which vary according to the morphology and distribution of lesions. In less than $0.2 \%$ of all lichen planus cases, the lesions are distributed along the lines of Blaschko, and is a variant called linear lichen planus. This is a case report of a patient aged two years and eight months, who presented keratotic violaceous papules, affecting the abdomen, buttocks and right thigh, distributed along the lines of Blaschko. Histopathological examination confirmed a diagnosis of linear lichen planus. Keywords: Child; Dermatology; Lichen planus
\end{abstract}

Resumo: O líquen plano é uma enfermidade pouco frequente na infância, apenas 2 a 3\% dos pacientes acometidos se encontram abaixo dos vinte anos de idade. Essa dermatose pode se apresentar sob várias formas clínicas, as quais variam de acordo com a morfologia e distribuição das lesões. Em menos de 0,2\% dos casos de líquen plano, as lesões se distribuem ao longo das linhas de Blaschko, variante denominada de líquen plano linear. Relata-se o caso de uma paciente de dois anos e oito meses de idade apresentando pápulas violáceas de superfície ceratósica acomentendo a região abdominal, região glútea e coxa direita, distribuídas ao longo das linhas de Blaschko, cujo exame histopatológico confirmou o diagnóstico de líquen plano linear.

Palavras-chave: Criança; Dermatologia; Líquen plano

\section{INTRODUCTION}

Lichen planus is an inflammatory dermatosis that may appear in several clinical forms, which vary according to the morphology and distribution of the lesions. In certain cases, lesions are distributed in a linear manner, usually due to the Koebner phenomenon. Less commonly, lichen planus is characterized by linear lesions that follow the lines of Blaschko, denominated linear lichen planus, representing less than $0.2 \%$ of all cases. ${ }^{1}$ Lichen planus in children is very rare, comprising only $2-3 \%$ of all affected patients. ${ }^{2,3}$ Although linear lichen planus is more common in children than in adults, its occurrence in children is extremely rare, which highlights the importance of even greater investigation so as to rule out other dermatoses with the same distribution pattern.
The report described below aims to demonstrate an uncommon clinical variant of lichen planus, generally considered rare among pediatric age groups.

\section{CASE REPORT}

A female patient aged two years and eight months, with a three-month history of asymptomatic lesions affecting the abdominal region. Examination indicated multiple violaceous papules with hyperkeratosical surfaces, distributed along the lines of Blaschko on the abdominal region, buttocks and right thigh (Figures 1 and 2). No mucosal lesions or ungueal alterations were discovered. Hepatitis $C$ serology was negative. Histopathological examination indicated vacuolar and lichenoid interface dermatitis with pigment incontinence, consistent with linear lichen planus

Received on 06.07.2012.

Approved by the Advisory Board and accepted for publication on 15.10.2012.

Work performed at the Ambulatório de dermatologia do Hospital Universitário Oswaldo Cruz - Universidade de Pernambuco (HUOC-UPE) - Recife (PE), Brasil.

Conflict of interest: None

Financial Support: None

Resident in dermatology at the Hospital Universitário Oswaldo Cruz - Universidade de Pernambuco (HUOC-UPE) in Recife, Pernambuco, Brazil.

PhD in Tropical Medicine, Universidade Federal de Pernambuco (UFPE) - Adjunct professor of Dermatology at the Universidade de Pernambuco (UPE) Recife (PE), Brazil.

Expert in pathology from Universidade Federal de Pernambuco (UFPE) and member of the Brazilian Pathology Society - Preceptor of dermatopathology at Hospital Oswaldo Cruz - Universidade de Pernambuco (HUOC-UPE) - Recife (PE), Brazil. 
(Figures 3 and 4). Treatment was initiated with topical steroids, to which there was a good response, with persistent residual hyperchromic stains (Figure 5).

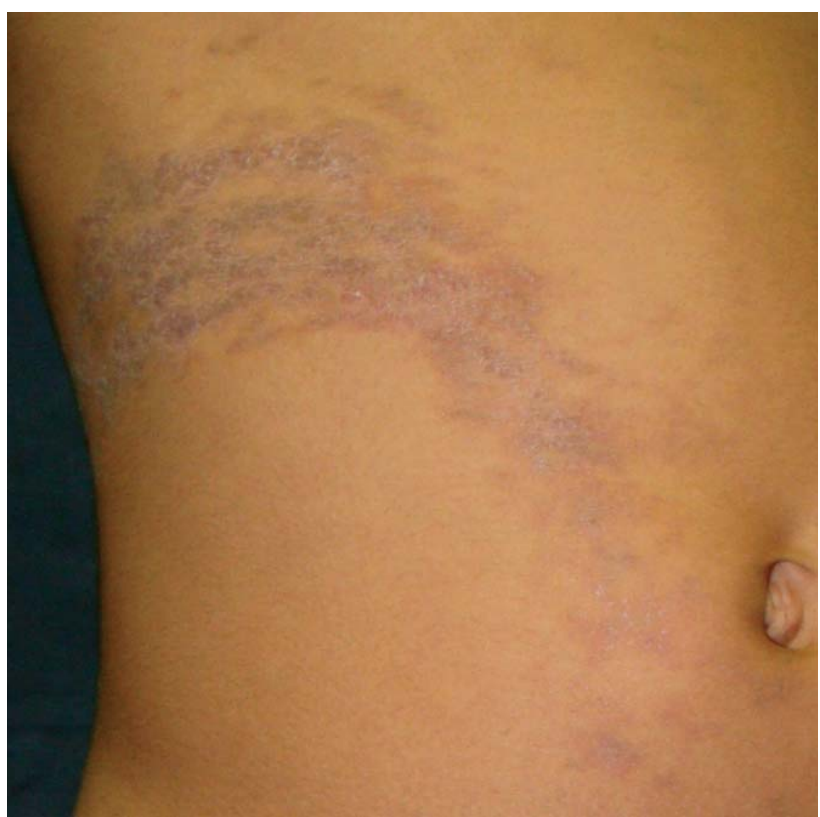

FIGURE 1: Violaceous papules with hyperkeratotic surface, distributed along Blascko lines on on the abdominal region

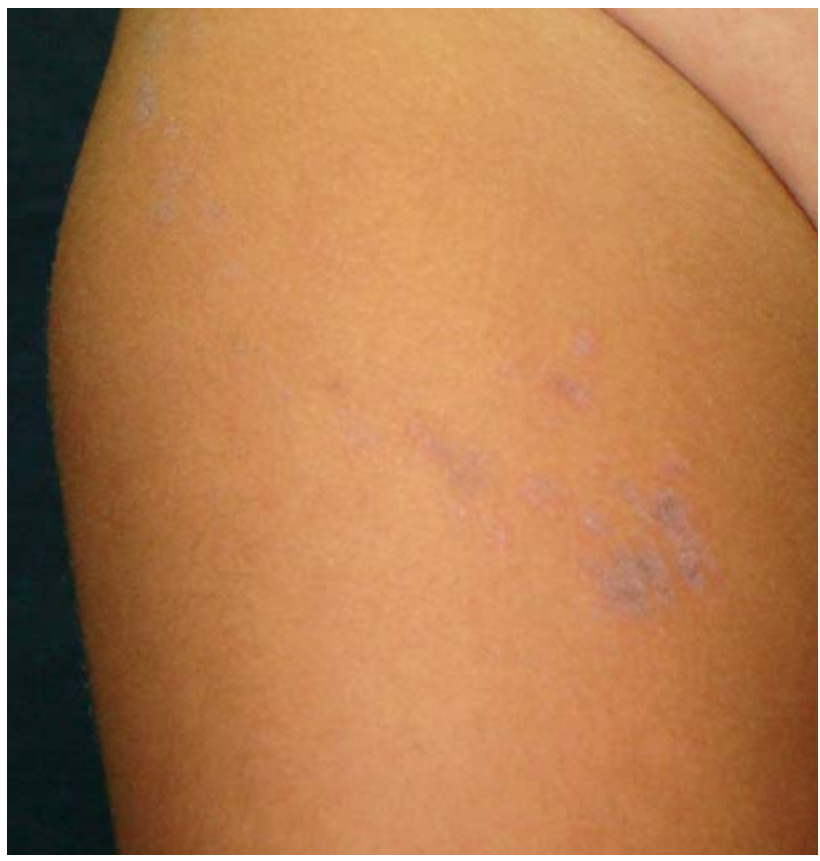

FIGURE 2: Violaceous papules with hyperkeratotic surface, distributed along Blascko lines on right thigh

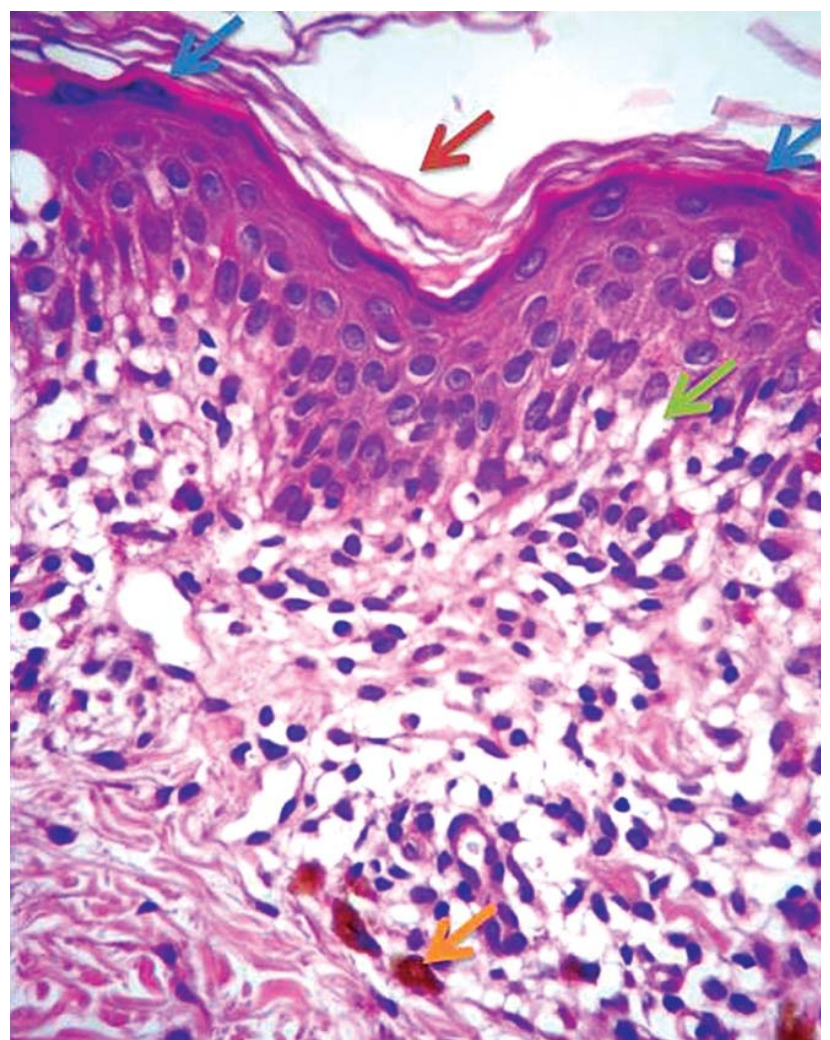

FIGURE 3: Vacuolar and lichenoides interface dermatitis with pigmentary incontinence, compatible with lichen planus. Arrows: basal layer colliquation (green), melanophages (orange), hyperkeratosis (red), wedge hypergranulosis (blue)

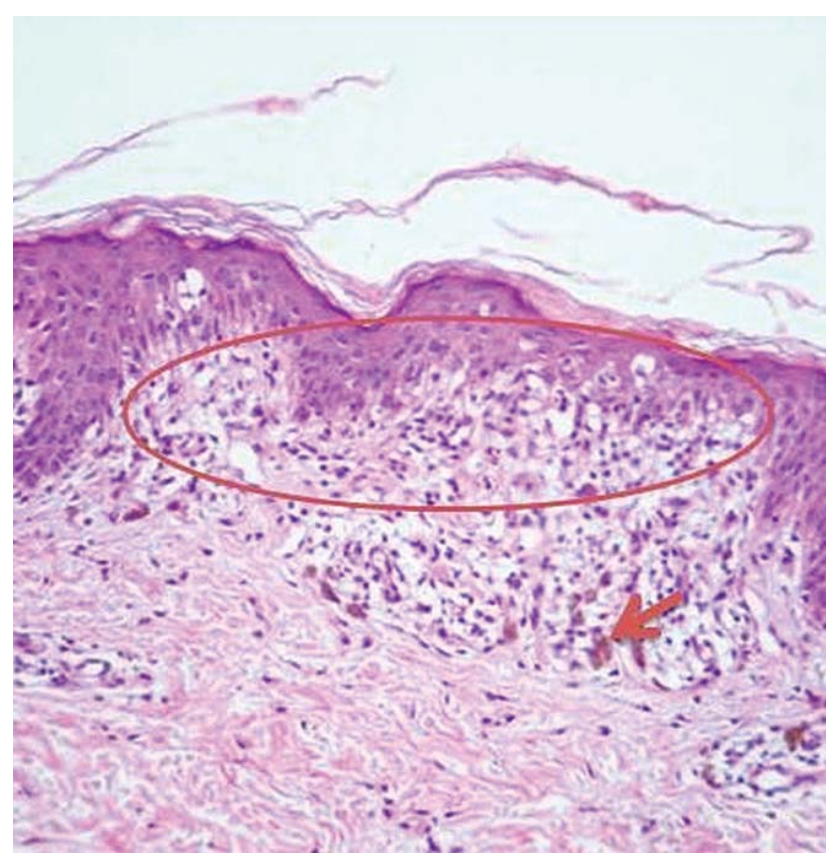

FIGURE 4: Strip Inflammatory infiltrate (circle), pigmentary incontinence (arrow) 


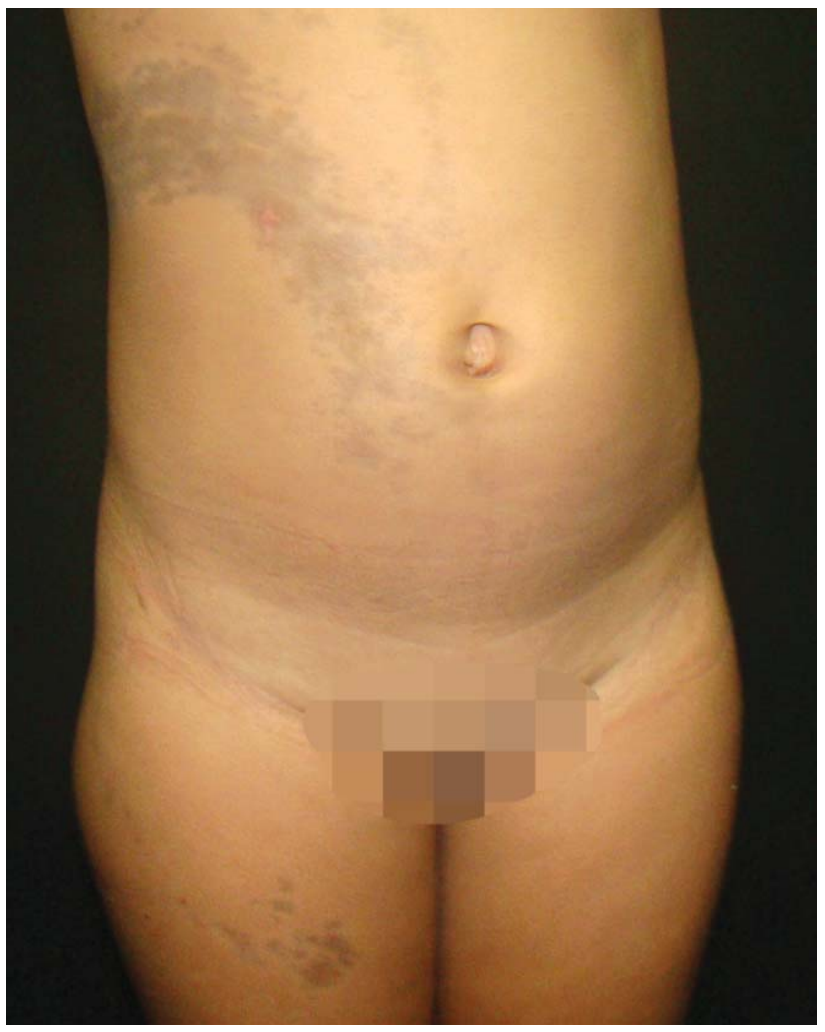

FIGURE 5: Residual hyperchromic macules after three months of topical steroids

\section{DISCUSSION}

Lichen planus is an inflammatory dermatosis characterized by violaceous, scaly, polygonal papules involving the flexor aspects of the wrists, lower limbs and the genital and oral mucosas. Lesions generally clear up within a few months to years, leaving areas of hyperpigmentation. It is believed that the pathogenesis is mediated by autoimmune $\mathrm{T}$ cells in response to viral agents, medication, allergens and even neoplasias. ${ }^{4,5}$

In a series of 87 pediatric patients with lichen planus, the classic form was most common, observed in $53(60.9 \%)$ patients, followed by lichen planus actinicus in $10(11.5 \%)$ patients, and both hypertrophic lichen planus and linear lichen planus, in 8 (9.2\%) patients. ${ }^{6}$

When cutaneous lesions are formed, they may either be randomly distributed or follow patterns established during embryonic development. ${ }^{7}$ As a result of cutaneous mosaicism, individuals may have distinct cell populations and are more prone to developing a dermatosis. Linear lichen planus is an example of this phenomenon.

Although lichen planus may occur in a liner pattern simply due to the Koebner phenomenon, the true linear form is more extensive and follows the lines of Blaschko, which are patterns of embryonic development. The lines of Blaschko were first described in 1901 and are based on the distribution of congenital and acquired dermatoses observed on the skin. Lesions that follow the lines of Blascko characteristically present S-shaped lines on the abdomen, Vshaped lines along the posterior midline, linear patterns on the lower trunk and limbs and snake-like patterns on the scalp and face. ${ }^{8}$

In histopathological examinations, linear lichen planus is identical to lichen planus, compact orthokeratosis, wedge-shaped hypergranulosis, irregular acanthosis with a sawtooth appearance, vacuolar alteration of the basal cells and band-like dermal lymphocytic infiltrate in close proximity to the epidermis. ${ }^{9}$

The differential diagnosis for linear lichen planus is dermatoses, which are also distributed along the lines of Blaschko, especially lichen striatus, inflammatory linear verrucous epidermal nevus (ILVEN), linear psoriasis, Blaschkitis and linear Darier-White disease, all of which present histopathological diferences (Chart 1).

Chart 1: The main differential diagnoses for linear lichen planus classified according to origin: congenital or acquired

\begin{tabular}{|ll|}
\hline Congenital & Acquired \\
\hline & - Linear psoriasis \\
- Pigmentary incontinencer & - Linear lichen planus \\
- Goltz syndrome & - Linear lupus erythematosus \\
- Inflammatory linear & - Linear lichen nitidus \\
verrucous epidermal & - Lichen striatus \\
nevus (ILVEN) & - Blaschkitis \\
\hline
\end{tabular}

One of the main differential diagnoses of this case report is ILVEN, due to the similarity of age group and clinical characteristics of the lesions. ILVEN is a linear pruriginous dermatosis, which consists of verrucous or hyperkeratotic papules that, unlike linear lichen planus, are generally present at birth or appear during childhood and do not regress spontaneously. ILVEN is histologically similar to epidermal nevi with a lichenoid infiltrate. ${ }^{8}$

Blaschkitis is the acquired linear dermatosis most frequently encountered in adults. Clinically, it is similar to linear lichen planus but occurs in bouts and histological findings present spongiotic dermatites. ${ }^{10}$

It is important to emphasize the rarity of the case presented in this report, since lichen planus represents an uncommon dermatosis in children, apart from which, linear presentation occurs in a minority of cases, with very few reports in the literature of unilateral multiple lesions. 


\section{REFERENCES}

1. Batra P, Wang N, Kamino H, Possick P. Linear lichen planus. Dermatol Online J. 2008;14:16.

2. Kanwar AJ, Handa S, Ghosh S, Kaur S. Lichen planus in childhood: a report of 17 patients. Pediatr Dermatol. 1991;8:288-91.

3. Nanda A, Al-Ajmi HS, Al-Sabah H, Al-Hasawi F, Alsaleh QA. Childhood lichen planus: a report of 23 cases. Pediatr Dermatol. 2001;18:1-4.

4. Issa MCA, Gaspar APA, Gaspar NK. Líquen plano e hepatite C. An Bras Dermatol. 1999;74:459-63.

5. Krasowska D, Pietrzak A, Lecewicz-Toruń B. Unilateral multiple linear lichen planus following the Blaschko lines recurring after deliveries. Dermatology. 2001;202:340.

6. Handa S, Sahoo B. Childhood lichen planus: a study of 87 cases. Int J Dermatol. 2002;41:423-7.

7. Chuong CM, Dhouailly D, Gilmore S, Forest L, Shelley WB, Stenn KS, et al. What is the biological basis of pattern formation of skin lesions? Exp Dermatol. 2006;15:547-64.

8. Kabbash C, Laude TA, Weinberg JM, Silverberg NB. Lichen planus in the lines of Blaschko. Pediatr Dermatol. 2002;19:541-5.

9. Mobini N, Toussaint S, Kamino H. Doenças eritematosas, papulares e escamosas não infecciosas. In: Elder DE, Elenitsas R, Murphy, GF, Johnson BL, Xu X, editores. Lever, histopatologia da pele. 10. ed. Rio de Janeiro: Guanabara Koogan; 2011. p. 161-93.

10. Müller CS, Schmaltz R, Vogt T, Pföhler C. Lichen striatus and blaschkitis: reappraisal of the concept of blaschkolinear dermatoses. Br J Dermatol. 2011;164:257-62.

\author{
MAILING ADDRESS: \\ Marcia Raquel Horowitz \\ Rua Arnóbio Marques, 310 - Santo Amaro \\ 50100-130 - Recife - PE \\ Brazil \\ E-mail:marciawitz@gmail.com
}

How to cite this article: Horowitz MR, Vidal ML, Resende MO, Teixeira MAG, Cavalcanti SMM, Alencar ERB. Linear lichen planus in children - a case report. An Bras Dermatol. 2013;88(6 Suppl 1):S139-42. 